\title{
Some Insights into Electoral Campaigning in the Age of Trump and Beyond
}

A Wuffle, University of California, Irvine

\author{
ABSTRACT This article examines some aspects of campaign strategies that have risen in \\ importance in twenty-first-century US political competition that are highlighted by the \\ events of January 6, 2021.
}

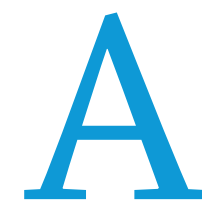

$s$ we contemplate the wreckage of American democracy in light of the events of January 6, 2021, and the groundwork that was carefully laid for those events during the past four years, it seems clear that there is a need to rethink how we view the logic of political campaigning. The following observations suggest how a masterful campaigner with no concern for long-term consequences can win the votes of very nearly a majority of the electorate and continue to persuade tens of millions of his followers to believe absurd conspiracy theories. Even when President Trump fades from the political scene-which will not happen overnight-the campaigning tools I identify will still be with us and used by others.

1. Hiram Johnson's Law: "The first casualty of war is truth." ${ }^{1} \mathrm{We}$ cannot understand recent political campaigns without recognizing that the struggle between conservatives and liberals and between Republicans and Democrats has become a "holy war"-a war for the soul of America. ${ }^{2}$

2. The Strategist's Rule: "Never tell a lie when a half-truth will do"3_or at least do not do so unless you think you can get away with it.

3. The John Wayne Rule: "If you are caught in a lie, never apologize." 4

4. The Hermann Goebbels Rule: "If at first you don't succeed, lie, lie again."

5. The Muddy-Wall Rule: "If you throw enough mud against a wall, some of it will stick." 5

A Wuffle (D) is an associate to Distinguished Professor at the University of California, Irvine. More than a dozen of his articles have appeared in PS during a period now spanning five decades (actually six decades, if we count "A Note on a Caveat," published in summer 1972 and written under a pseudonym), with at least one article in PS in each decade. Wuffle was a major contributor to Sigelman, Newton, Meier, and Grofman (eds.), The Wit and Humor of Political Science, jointly published in 2010 by the American Political Science Association and the European Consortium for Political Research. He can be reached at BGTravel@uci.edu.
6. The Maurice Chevalier Rule: "You don't have to be a well-liked candidate; you just need to be more well liked than your opponent." 6

7. The Totalitarian's Rule: "If you can control the media to constrain what people see, read, and hear, you can control what people think."

8. The "Fake News" Corollary to the Totalitarian's Rule: Candidates should seek to persuade voters to limit themselves to only those sources of information that will reinforce their message by persuading them that it is not necessary to look at other sources because they are only purveying "fake news." As Zaller (1992) pointed out, the probability of persuasion is the product of the likelihood of persuasion if a message is received multiplied by the probability that the message will actually be received.?

9. The Echo-Chamber Rule: "Verification from multiple sources is no guarantee of truth if they all repeat the same lie, but it does make the lies more credible."

10. The Adlai Stevenson Rule: "Nobody ever won an election by overestimating the intelligence of the American voter."

11. The Cheers Rule: "Politics is a place where you want voters to remember your name." 9 Note that catchy slogans help-for example, "I like Ike" and "Tippecanoe and Tyler, too."

12. The Permanent Campaign Rule: If you have to wait for an actual election campaign to reinforce your supporters' view of you and the world, it is almost certainly too late. Thus, we see Donald Trump as his own 24-hour, nonstop news and tweeting network: all Trump, all the time.

13. The Make Ambiguity Work for You Rule: Use slogans the substantive contents of which can be self-defined by voters but that have a positive penumbra-for example, "Make America Great Again" and "It's Morning in America." 10

14. The Two-Strategies Rule: There is an unavoidable tradeoff between seeking to persuade undecided voters and seeking to maximize turnout of your own supporters because these two strategies lead to differences in the potentially vote-maximizing policy platforms that will be proposed. Because we are living in an era when (a) presidential elections are expected to be close 
and (b) politics is highly polarized, elections are more likely to be won or lost by who shows up at the polls. Thus, "mobilizingthe-base" strategies have become more prevalent because they are now more likely to be efficacious. ${ }^{11}$

15. The Deleted-from-the-Desktop Rule: If those voters you think will vote the wrong way can be eliminated from the voter rolls or discouraged from voting, then it is not necessary to try to persuade them to vote for you. This exclusion can be done in various ways, from historically tried-and-true methods such as

\section{NOTES}

1. Hiram Johnson, a staunchly isolationist senator from Idaho, said this in 1918. A still earlier quote is from Samuel Johnson, who said in 1758: "Among the calamities of war may be jointly numbered the diminution of the love of truth by the falsehoods which interests dictate and credulity encourages."

2. That Republicans and Democrats are more deeply divided than ever, and that the Trump presidency exacerbated existing trends in partisan divisions, is simply indisputable (see, e.g., Bartels 2020). My own favorite indicator is the willingness to have your child marry someone of the opposite party. According to Klein and Chang (2015; citing Iyengar and Westwood 2015):

\section{We cannot understand recent political campaigns without recognizing that the struggle between conservatives and liberals and between Republicans and Democrats has become a "holy war"-a war for the soul of America.}

biased implementation of literacy tests and the burning of crosses, to more modern techniques such as purging voter rolls and ensuring that polling booths are few and lines are long in
In 1960, Americans were asked whether they would be pleased, displeased, or unmoved if their son or daughter married a member of the other political party. Respondents reacted with a shrug. Only

Because we are living in an era when (a) presidential elections are expected to be close and (b) politics is highly polarized, elections are more likely to be won or lost by who shows up at the polls. Thus, "mobilizing-the-base" strategies have become more prevalent because they are now more likely to be efficacious.

areas where your opponents reside. ${ }^{12}$ Of course, you also can simply demand that the vote count be stopped while you are still ahead.

16. Stalin's [sic!] Rule: ${ }^{13}$ "It isn't the people that vote who count, it's the people who count the votes." ${ }^{4}$

17. Ferejohn's Law: ${ }^{15}$ "Preference for outcomes conditions preference for institutions." In particular, the desirability of any set of electoral rules is determined by whether it was you or your opponent who won under them. ${ }^{16}$ Compare "The Electoral College is a disaster for democracy" (Donald Trump, November 6, 2012) to "The Electoral College is actually genius in that it brings all states, including the smaller ones, into play" (President-Elect Donald Trump, November 15, 2016).

18. Clausewitz's Rule (updated version): "Litigation is the continuation of political war by other means; if you can't win in the polling booth, try for a win at the courthouse." ${ }^{17}$

19. The Rule about Rules: If you can't win under the present rules, then change the rules. ${ }^{18}$

20. The Gospel of St. Majority: ${ }^{19}$ "What shall it profit a (wo)man if (s)he gains the popular vote and loses the Electoral College?"

21. The Joe Jacobs Rule: If you lose an election that is even reasonably close, simply utter these immortal words: ${ }^{20}$ "We wuz robbed." Better still, prepare the groundwork by warning your supporters well in advance that the election is sure to be stolen by noncitizen voting and mail-in-ballot corruption. And take so many extreme actions to protest the legitimacy of the results and to overturn them that no supporter can doubt that you sincerely believe in the fraud (even when you do not) and that, therefore, they should believe too.
$5 \%$ of Republicans and only $4 \%$ of Democrats said they would be upset by the cross-party union. On the list of things you might care about in your child's partner-are they kind, smart, successful, supportive?-which political party they voted for just did not rate. Fast forward to 2008. The polling firm YouGov asked Democrats and Republicans the same question-and got very different results. This time, $27 \%$ of Republicans and $20 \%$ of Democrats said they would be upset if their son or daughter married a member of the opposite party. In 2010, YouGov asked the question again; this time, $49 \%$ of Republicans and $33 \%$ of Democrats professed concern at interparty marriage.

3. By a "half-truth," I mean something that is technically true but is far from the whole truth or that is used to suggest an implication that is a lie. Half-truths usually are told with an intent to deceive. For example, it is true that President Biden had negative coattails-that is, Democrats suffered a net loss of seats in the US House of Representatives. It is not true, of course, that such a fact implies massive voter fraud. The mean magnitude of presidential coattails has been declining, and my projection of past results along with consideration of the number of House seats held by Democrats won by Trump in 2016 compared to the number of House seats held by Republicans won by Hillary Clinton in 2016 suggested that it could turn negative in 2020 .

4. What John Wayne's army-officer character actually said (in the 1948 classic Hollywood western, "She Wore a Yellow Ribbon") was: "Never apologize, it's a sign of weakness." Also see next rule.

5. I learned this rule from the late civil rights attorney, Frank Parker. The context was the idea of throwing many, many legal and factual arguments into a brief in the hope that one or more might prove persuasive to a judge. In arguing for absurdities, it can be especially helpful to amass numerous disparate arguments Doing so has a double-barreled effect. First, it makes the evidence seem more difficult to dispute because even if some of the arguments seem pathetically weak or factually unsupported, there simply are so many of them that operate seemingly to reinforce one another that it can be difficult to believe that they are all wrong. Second, different arguments might well seem compelling to different members of your audience.

6. When asked by a reporter how he felt about turning 70, the legendary French singer and actor Maurice Chevalier famously replied: "Well, consider the alternative!"

7. See also Grofman (2020). 
8. There is an old joke that makes this point. Someone read a story in one newspaper and then picked up two other newspapers with exactly the same story, asserting: "Well, it must be true, everybody is saying it." Of course, the story is simply being copied more or less verbatim from the AP Wire.

9. Of course, if voting is entirely along party lines-as in the famous definition of a "yellow-dog Democrat" as a voter who would always support the Democrat over the Republican even if the Democratic candidate were a "yaller dog"-then knowing names of candidates is not necessary. Although the proportion of such voters within each party may have risen despite the increase in those who identify as independents, the number of voting places where a single lever allows a straight party vote has been steadily declining.

10. I label such slogans as ppempties-that is, empty of content but with positive penumbra.

11. In as yet unpublished work, Merrill, Grofman, and Brunell (2021) provide formal modeling in support of this proposition.

12. You also can do this by reducing the period for early voting or you can claim-as Donald Trump tweeted in early August 2020-that it is OK to have mail-in ballots in states that your party won in 2016 (e.g., Arizona and Florida) but not OK in states that your party lost in 2016 (e.g., Nevada). Bills to restrict access to mail-in ballots are currently pending in a number of Republican-controlled legislatures. Moreover, you can affect election outcomes even more indirectly, but potentially quite effectively, by changing the rules for apportionment-as in President Trump's proposal to remove aliens who are in this country illegally (i.e., those who never passed through US customs or whose visas have expired) from the census count for apportionment purposes.

13. Alas, it appears that Stalin never actually said this (www.politifact.com/factch ecks/2019/mar/27/viral-image/no-joseph-stalin-didnt-say-statement-aboutelection), but the Ayatollah Khamenei and many other dictators who permitted sham elections could easily endorse the sentiment. Even genuine winners (e.g. Vladimir Putin) almost certainly have carefully padded the margins of their victory to discourage future opposition and enhance their own legitimacy.

14. Well before President Trump's efforts to directly suborn the election via intimidation of election officials and attempts to convince state legislatures to override the state's own voters, I wrote in an earlier draft of this article: "The shoe that is waiting to drop is to see if we have a repeat of 1876 , when two competing sets of presidential election returns came in from a handful of states." The 1876 dispute, involving a few Southern states with Reconstruction-era governments still in power, was settled only when the Democrats agreed to accept Rutherford $\mathrm{B}$. Hayes as the victor in return for the Republicans agreeing to end Reconstruction in the South. We were spared competing presidential slates in 2020, but the groundwork has been laid for such an event in 2024.

15. I am fairly certain that I first heard this elegant single-sentence summary of public-choice theory from John Ferejohn at a conference in Hilton Head Island, South Carolina, in 1971. However, I am not sure he remembers saying it-then again, neither of us is as young as we used to be.

16. After Baker v. Carr forced decennial redistricting on states that had failed for decades to do so, and after cases such as Reynolds v. Sims began enunciating the standards for "one person, one vote," opposition by members of the House of Representatives representing districts that would be affected was fierce. There was a call for a constitutional amendment to allow for considerations other than population to shape redistricting. However, after there had been elections under the new rules, it was remarkable how the set of legislators elected under those rules did not seem nearly as bothered by the rule's effects.
17. It is not only the Republicans in the 2020 election; cf. the 2000 presidential election-when litigation about what was to be done to complete/stop the count in Florida came from both sides.

18. Rule 15 identifies common institutional mechanisms for voter suppression and reducing turnout. These methods, or variants thereof, are all being proposed as alleged anti-corruption devices by Republican-controlled legislatures in closely divided states. However, there also is the "nuclear option." Highly gerrymandered state legislatures in trifecta states could decide-in advance of the 2024 electionto give themselves the authority to determine the presidential winner in their state. Article II, Section 1, of the Constitution states that electors shall be chosen "in such manner as the state legislature thereof may direct." The last time a state legislature chose the state's electors apparently was Colorado in 1876 . However, until the 1820 s, this was common practice in several states, including Connecticut, Delaware, Georgia, Louisiana, New York, South Carolina, and Vermont, with sporadic use of this mechanism in another half dozen or so states (Martin 1958, 1185-87). Martin, an Alabamian, wrote his 1958 essay in objection to the expansion in the scope of government in the post-New Deal era, arguing for a return to legislative choice of electors to enhance the powers of the states vis-á-vis the federal government.

19. Cf. Mark 8:36 in the Holy Bible, King James Version.

20. "This expression has been attributed to fight manager Joe Jacobs (1896-1940), who uttered it on June 21, 1932, after his client, Max Schmeling, had clearly outboxed Jack Sharkey, only to have the heavy-weight title awarded to Sharkey" (www.dictionary.com/browse/we-wuz-robbed). Of course, the claim also can be made by those who were defeated in a fair fight and simply want to avoid being labeled as "losers."

\section{REFERENCES}

Bartels, Larry. 2020. "Under Trump, Democrats and Republicans Have Never Been More Divided, on Nearly Everything." Washington Post, May 21.

Grofman, Bernard. 2020. "Reasoned Persuasion." In Oxford Handbook of Electoral Persuasion, ed. Elizabeth Suhay, Bernard Grofman, and Alex Trechsel. Oxford: Oxford University Press.

Iyengar, Shanto, and Sean J. Westwood. 2015. "Fear and Loathing Across Party Lines: New Evidence on Group Polarization.” American Journal of Political Science 59 (3): 690-707.

Klein, Ezra, and Alvin Chang. 2015. "Political Identity Is Fair Game for Hatred: How Republicans and Democrats Discriminate." Vox, December 7. www.vox.com/2015 12/7/9790764/partisan-discrimination.

Martin, William Logan. 1958. "Presidential Electors: Let the State Legislatures Choose Them." American Bar Association Journal 44 (12): 1182-87.

Merrill, Samuel, Bernard Grofman, and Thomas Brunell. 2021. "Why Does Polarization Make Appealing to One's Base More Attractive?" Unpublished manuscript.

Sigelman, Lee, Kenneth Newton, Kenneth J. Meier, and Bernard Grofman (eds.). 2010. The Wit and Humor of Political Science. Washington, DC, and Colchester, UK: American Political Science Association and the European Consortium for Political Research.

Zaller, John. 1992. The Nature and Origins of Mass Opinion. New York: Cambridge University Press. 